\title{
Application of Animal Manure and Plant Growth- Promoting Rhizobacteria as Effective Tools to Control Soil Nematode Population and Increase Crop Yield in Grapevine Orchards
}

\author{
Ramadan M. El-Ashry \\ Dept. Plant Protection, Fac. Agric., Zagazig Univ., Egypt. \\ E-mail corresponding author: mrmaa2010@yahoo.com \& rmelashry@agri.zu.edu.eg. \\ Revised: 30 December 2020 \\ Accepted:15January2021
}

Received: 29 November 2020

\begin{abstract}
A survey of nematode community in grapevine plantations grown in Belbes, Sharqia, Egypt revealed the presence of nine plant-parasitic nematodes genera namely Aphelenchus, Criconemoides, Ditylenchus, Helicotylenchus, Pratylenchus, Meloidogyne, Longidorus, Tylenchus and Tylenchorhynchus; free-living nematodes (FLNs) belonging to the genus Rhabditis and predacious nematodes (PNs) belonging to order Mononchida. Nematodes were found with a different frequency of occurrence and population density. Pratylenchus gained a high population density (PD) followed by Tylenchus, Meloidogyne and Helicotylenchus. A higher prominence value (PV) was found with genus Pratylenchus (190.75) while, the genera Meloidogyne, Tylenchorhynchus and Tylenchus were found with moderate prominence values. Animal manures are effective tools in sustainable soil health and agricultural systems. Therefore, the influence of three livestock manures as feasible practices with BECTO Grow Roots®, a commercial plant growth-promoting bacterium (PGPB) on nematode community and plant growth and fruit yield of grapes, Vitis vinifera L. cv. Flame was undertaken. Soil samples were collected at five-time intervals. Composted animal manures significantly $(P \leq 0.05)$ minified numbers of plant-parasitic nematodes (PPNs). The greatest effect was recorded with oxamyl after two months of treatments followed by chicken, sheep and cow manure. Conversely, at four and five months after application, animal manures were the most effective. Moreover, a noticeable abundance of FLNs and PNs numbers was detected. The highest increment was achieved in soil amended with chicken manure followed by sheep and cow manure whereas oxamyl reduced numbers of FLNs and PNs as compared with untreated vines. Application of manures against PPNs particularly M.incognita decreased numbers of $\mathrm{J}_{2} / 250 /$ soil in vines amended with chicken, cow and sheep manure, respectively and increased numbers of FLNs and PNs. Population densities of M.incognita $\mathrm{J}_{2} / 250 \mathrm{~g}$ soil were significantly minimized $\left(1.55 \mathrm{~J}_{2} / 250 \mathrm{~g}\right.$ soil) in blocks amended with commercial rhizobacteria and chicken manure. Maximum total fruit weight and leaf numbers were achieved in vines treated with rhizobacteria +chicken, cow and sheep manure, respectively. This study proved that composted chicken, cow and sheep manure applied alone or in combination with PGPB can be a promising tool for the management of phytoparasitic nematodes, enrichment of FLNs and PNs and improvement of plant growth and grapevine yield.
\end{abstract}

Keywords: survey, nematode community, grapevine fields, animal manures, plant growth-promoting rhizobacteria (PGPR). 


\section{INTRODUCTION}

Grapevine, Vitis vinifera L. is an economic fruit in Egypt and the Mediterranean area. Flame and Thompson seedless are important cultivars. Egypt's production of grapes fruits in 2019 was estimated as 1.75 million tons (Omar and Akingbe, 2020). Nowadays, current agriculture practices are moving to a more sustainable and eco-friendly approach and organic farms for high added-value crop growers' income (Yang et al., 2016). Numerous pathogenic microorganisms have been found to infect grapevine but plantparasitic nematodes (PPNs) are the greatest challenges facing the expansion of viticulture plantations in Egypt. Damage caused by PPNs infestation in vine growth and productivity ranged from 12.5-20.0\% (Kesba, 1999).

Among plant-parasitic nematodes (PPNs), Meloidogyne spp. (root-knot nematodes), Heterodera and Globodera sp. (cyst nematodes) and Pratylenchus spp. (lesion nematodes), Helicotylenchus spp. (spiral nematodes) and Tylenchorhynchuss spp. (stunt nematodes) are considered as the most economically important species (Schneider et al., 2003).

The most widespread RKNs (Meloidogyne spp. Göldi) comprise up to four common Meloidogyne species (Meloidogyne incognita, M. javanica, M. hapla and Marenaria). The infected grapevine suffers malformation plant roots, galls formation which adversely affects nutrient and water uptake, subsequently plant growth and productivity (McCarter,2008; Kepenekci et al., 2016) and forced to apply nematicides intensively and fumigants in epidemic case explain (Zasada et al., 2010). The main responsible for most of them is root-knot nematodes (RKNs) M. incognita (El-Gendy and Shawky, 2006).

Nematodes are abundant and typically belong to eight trophic groups (Yeates et al., 1993) and five easily identified: bacterivores, fungivores, obligatory plant parasites, predators ( $1 / 4$ carnivores) and omnivores. The high soil microbial diversity might be enhancing soil ecosystem flexibility in favor of the plant (Giné et al., 2016). A complicated association between plant productivity with the economic damage of PPNs and free-living nematodes (FLNs) (Yeates, 1982) is documented. But PPNs damage potentially interacts with associated-crop, and the initial population at planting time and nematode trophic groups in the community such as [(Free-living nematodes and predaceous nematodes (PNs) as well as, genera, species, and abundance of such nematodes may be used as bioindicators of soil health (Neher, 2001).

Various factors affected density/biomass patterns and structure of nematode communities subsequently soil characteristics. From these factors, soil type and its nutrient content besides $\mathrm{pH}$, however, climatic restrictions as temperature and rainfall regimes are the more efficient (Bhusal et al., 2014). Recycling composted livestock animal manures to agricultural land is a beneficial management option(Nicholson et al., 2005) that might be used to reduce pathogenic levels (Hassen et al., 2001; Lemunier et al., 2005)as a source of plant nutrients and organic matter. Besides the soil physical and chemical improvement, stimulation of FPNs and PNs to suppress of PPNs directly or indirectly (Akhtar and Alam, 1993; Sukul,1992). Soil biota is at the core of soil health (Ferris and Tuomisto, 2015). The abundance and activity of soil microorganisms are enhanced by fertilizer inputs (Geisseler and Scow, 2014). But the diversity and species composition significantly depending on the type of supplied 
compounds (i.e. organic or inorganic) (Liu et al., 2016), and changes in food web structure lead to changes in soil ecosystem services such as $\mathrm{C}$ and $\mathrm{N}$ cycling (de Vries et al., 2013).

Introducing plant growth-promoting bacteria (PGPB) enhance plant growth and increase tolerance against biotic and abiotic stresses. Besides their role in reducing the RKN population (Osman et al., 2018; El-Ashry, 2020) alone or combined with animal manures like chicken and cow.

The study aimed to survey the common soil-borne nematode genera associated with grapevine plantations grown in Belbes, Sharqia Governorate, as well as an evaluation of the effectiveness of composted animal manures (chicken, cow and sheep) on nematode community structure in amended or non-amended habitats. Furthermore, the effect of composted animal manures (organic manures) and plant growth-promoting bacteria (PGPB) on free-living and predaceous nematodes in soil and their consequences on plant growth/total fruit weight per vine was undertaken.

\section{MATERIALS AND METHODS}

\section{Experimental Site Description:}

The survey was made on the soil-borne nematodes associated with grapevine (Vitis vinifera L.) var. Flame. The investigated area is located in Tahawia, Belbes district, Sharqia Governorate, Egypt. The area represents approximately 21 ha (Fig.1). The study site is mainly concerned with organic grape production intended for export. The farm is committed to using biopesticides e.g. NemaStop ${ }^{\circledR}$ for the control of plant-parasitic nematodes and soils did not receive any chemical pesticides for 25 years. The drip irrigation system and the traditional horticultural treatment were implemented.

\section{Nematode sampling, Extraction and Identification:}

A survey of plant-parasitic nematodes (PPNs) infestation on grapevine (Vitis vinifera L.) var. Flame and associated, free-living nematode (FLNs) and predaceous nematodes (PNs)] was undertaken between 2018 and 2019. Grapevine plantations were grown in about 82 feddan sandy area $(75.2 \%$ sand, $14.8 \%$ clay, 9. $2 \%$ silt and 0.8 organic matter), Khomasia Group Company for Agriculture Investment in Belbes, Sharqia Governorate. The plants were irrigated with a drip irrigation system. A total of 192 soil and root samples were collected from the rhizosphere of the grapevine at a depth of about $12-25 \mathrm{~cm}$ from a single spot near the trunk of 10 vines randomly selected from the sample area. The number of sites sampled per day varied according to the extent of sampling and the distance between the sites. Each sample was made of three subsamples mixed to form a composite sample of about $1 \mathrm{~kg}$ placed in labeled polyethylene bags and kept in an icebox at approximately $18^{\circ} \mathrm{C}$ sent directly to the laboratory for nematode extraction.

Nematodes extraction were processed by using an aliquot sample of $250 \mathrm{~g}$ and extracted using a combination of sieving and Baermann trays technique (Hooper et al., 2005). One $\mathrm{ml}$ of nematode suspension was pipetted into Hawksely counting slide and nematodes were examined with the aid of the research microscope under $100 \mathrm{X}$ magnification. Nematode identification was based on the morphology of adult and juvenile forms according to Mai and Lyon (1975) and Siddiqi (1986). 


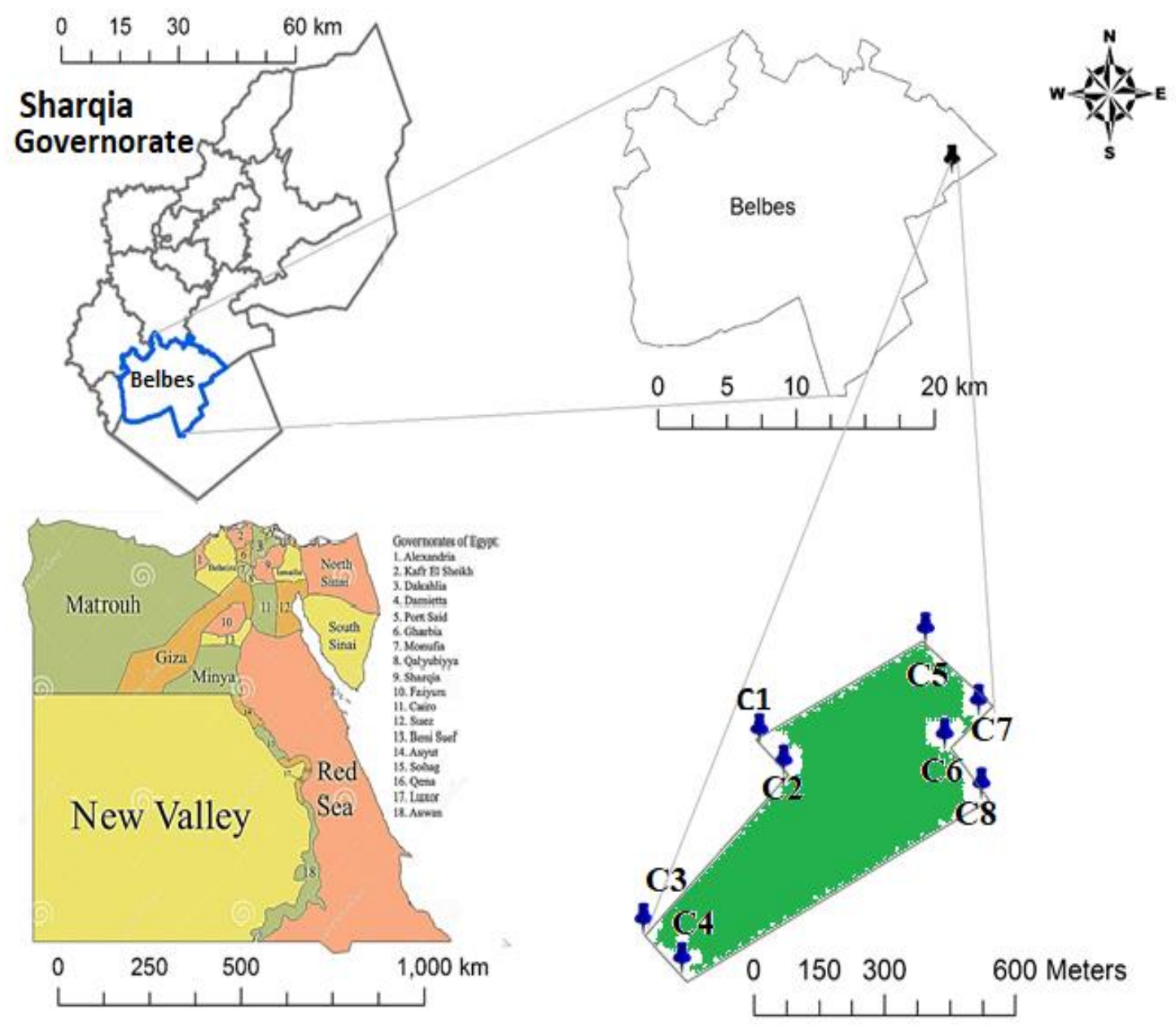

Fig. 1. Map showing locations of the grapevine plantations of Khomasia Group Company for Agriculture Investment in Belbes, Sharqia Governorate, Egypt. Sampling sites are indicated by $\mathrm{C} 1, \mathrm{C} 2, \mathrm{C} 3, \mathrm{C} 4, \mathrm{C} 5$ and $\mathrm{C} 6$.

\section{Frequency of occurrence, and prominence value of PPNs infesting grapevine:}

Frequency of occurrence and prominence value was calculated according to Norton (1978) as follows:

Absolute Frequency of occurrence (\%)

$$
=\frac{\text { Number of samples containing a genus }}{\text { Number of collected samples }} \times 100
$$

Relative frequency of occurrence (\%)

$$
=\frac{\text { Absolute frequency of occurrence of genus }}{\text { Sum of absolute frequency of occurrence of all genus }} \times 100
$$

Prominence value /each species

$$
=\text { Population density } \times \sqrt{\% \text { Frequency of occurrence }}
$$

\section{Livestock manures analysis and structure:}


Physical and chemical analyses of composted chicken, cow, and sheep manure applied as nutrients or curative treatments in tested areas of vegetable plants were measured. $\mathrm{pH}$, salinity, electrical conductivity (EC), organic matter, organic carbon, total nitrogen, and phosphorus, were analyzed according to Official Methods for Fertilizer Analysis (Leege and Thompson, 1997). Three composted livestock manures included chicken, cow, and sheep manures were applied during the growing season of grapevine 2018 and 2019. Livestock manures used in the study were subjected to physical and chemical analysis as elucidated in Table (1).

Table 1. Physical and chemical characteristics of different animal manures (cow, sheep, and chicken manure).

\begin{tabular}{|c|c|c|c|}
\hline Parameters & Chicken manure & Cow manure & Sheep manure \\
\hline Density $\left(\mathrm{kg} / \mathrm{m}^{3}\right)$ & 450 & 500 & 480 \\
\hline Moisture content (\%) & 13.60 & 58.50 & 21.80 \\
\hline pH (1: 10) & 8.41 & 9.32 & 7.95 \\
\hline EC (1: 10) (dS/m) & 3.66 & 3.54 & 3.41 \\
\hline Total - nitrogen $(\%)$ & 3.55 & 1.57 & 1.09 \\
\hline Ammoniacal - N (ppm) & 9.82 & 342 & 251 \\
\hline Nitrate - N (ppm) & 86 & 219 & 129 \\
\hline Organic matter (\%) & 68.19 & 68.36 & 67.85 \\
\hline Organic carbon (\%) & 39.62 & 39.69 & 38.66 \\
\hline $\operatorname{Ash}(\%)$ & 31.92 & 31.66 & 30.55 \\
\hline $\mathrm{C} / \mathrm{N}$ ratio & 11.6: 1 & 26.4: 1 & 18.2: 1 \\
\hline Phosphorus (\%) & 0.73 & 0.41 & 0.42 \\
\hline Potassium (\%) & 1.42 & 1.76 & 1.51 \\
\hline NPK ratio & $1.1: 0.8: 0.5$ & $0.6: 0.4: 0.5$ & $0.7: 0.3: 0.9$ \\
\hline
\end{tabular}

\section{Evaluation of the effectiveness of livestock animal manures and rhizobacteria against PPNs under field conditions:}

Two separate field experiments were conducted in sandy soil naturally infested with PPNs, the same surveyed area has grown with grapevine (25 years old) cv. Flame during the 2019 season. Preliminary soil samples were collected to determine nematode genera. Plant-parasitic nematodes (PPNs), as well as predaceous and free-living nematodes, were enumerated. The current investigation was done to determine changes in the number of important nematode species related to grapevines such as root-knot nematode (RKN) $M$. incognita besides nematode genera such as Tylenchorhynchus, Pratylenchus, Helicotylenchus and Tylenchus. with the fluctuations in numbers of free-living and predaceous nematodes in soil samples collected monthly for 5 months following treatment of composted animal manures individually or in combination with rhizobacteria.

The first field experiment was conducted to evaluate the effectiveness of composted animal manures on the nematode population at 1, 2, 3, 4- and 5-months post-treatment. The treatments included: composted chicken manure $(12 \mathrm{Kg} /$ vine or 4.98 tons/feddan), composted cow manure and composted sheep manure (15 Kg/vine or 6.64 tons/feddan) and oxamyl (Vydate 24\% SL, 5liters/feddan). Besides, the negative control did not 
receive any treatment. Oxamyl used as reference nematicide is considered as the positive control.

The second field experiment was carried out to evaluate the combined effect of animal manures and rhizobacteria on nematode population (suppression of PPNs or promoting of predaceous and free-living nematodes) and plant growth of the vine.

The commercial bioproduct, BECTO Grow Roots ${ }^{\circledR}$ (15 liters/feddan of $10^{8} \mathrm{CFU} / \mathrm{ml}$ included Serratia marcescens and Pseudomonas putidalfluorescens). The formulation of rhizobacteria was added to the water irrigation system during the growing season of vines.

The measured parameters included: population densities of plant-parasitic nematodes (initial population), as well as, nematode population (number of $\mathrm{J}_{2}$ Meloidogyne, freeliving nematodes and predacious nematodes $/ 250 \mathrm{~g}$ soil. Also, grapes physical growth parameters included leaf numbers/vine which was manually calculated before harvesting fruits by 10 and 60 days. While fruit yield/vine (total weight of fruit/vine) were evaluated at the time of harvesting (at once after-ripening) from each tested vine.

\section{Statistical analysis}

The experimental units were laid out in a randomized complete block design in the field experiment. Data were subjected to statistical analysis using MSTAT version 4, where, analysis of variance and means were compared using Duncan's multiple range test at $P \leq$ 0.05 probability.

\section{RESULTS AND DISCUSSION}

\section{Frequency of occurrence (FO), population density (PD) and prominence value (PV) of plant-parasitic nematodes infecting grapevine:}

Nine genera of true plant parasites (stylet- bearing) and suspected parasites with less economic importance nematodes were found in the rhizosphere of grapevine, Vitis vinifera $\mathrm{L}$. These genera were the ring nematodes Criconemoides, the spiral nematodes Helicotylenchus, the needle nematodes Longidorus, the root-knot nematodes Meloidogyne, the lesion nematodes Pratylenchus, the stunt nematodes Tylenchorhynchus while Aphelenchus and Tylenchus were identified as suspected parasite nematodes.

Free-living nematodes mainly genus Rhabditis and predacious nematodes belonging to order-Mononchida were detected in the collected samples. Meloidogyne, Pratylenchus; and Tylenchorhynchus were the most frequently genera of true phytonematodes and their $\%$ FO were 62.92, 23.59 and 21.34\%, respectively (Fig.1).

Based on perineal pattern examination, Meloidogyne species were identified as M.incognita. FO and PD for some of the identified genera varied from one region to another. Due to differences in the arrangement according to FO and PD, the relationship of both parameters was calculated as prominence value (PV). It could be concluded that the genus Pratylenchus was found with a relatively higher prominence value followed by Meloidogyne, Tylenchus and Helicotylenchus while the genera Aphelenchus, 
Tylenchorhynchus, Ditylenchus, Longidorus and Criconemoides were found with moderate and low prominence values.

\section{Responses of nematode genera to composted animal manures and oxamyl at different time intervals}

In treated grapevine fields with the recommended rate of animal manures (chicken, cow and sheep) and oxamyl, plant-parasitic nematodes (PPNs) and free-living nematodes (FLNs) belong to genus Rhabditis and predaceous nematodes (PNs) going to order: Mononchida were varied greatly. Nematode community analysis revealed that nematode abundance or reduction was significantly affected by composted animal manures and period intervals during the years of the study (Table 2, Fig.3\&4).

In respect to the effectiveness of the tested materials on PPNs, results in Table (2) clearly showed that oxamyl, chicken, cow and sheep manures significantly $(P \leq 0.05)$ minified numbers of Helicotylenchus, M.incognita, Pratylenchus, Tylenchorhynchus and Tylenchus compared to untreated (control) treatment. However, chicken manure followed by sheep manure insignificantly achieved the highest effect on parameters with oxamyl while cow manure achieved the lowest significant effect.

After three months of application, chicken manure was the most effective in reducing PPNs while other tested materials were less effective and thus phytonematodes numbers were increased (Fig.3 a, b, c, d, e). After four and five months, mean numbers of Helicotylenchus, M. incognita, Pratylenchus, Tylenchorhynchus and Tylenchus were noticeably decreased. Population density of Helicotylenchus spp. was decreased significantly $(P \leq 0.05)$ after $1,2,3,4$ and 5 months of treatment with tested materials compared to positive treatment with significant differences between oxamyl (23.72) and chicken (24.68), cow (45.84) and sheep (40.80), manures. On the other hand, slightly significant differences were detected between chicken manure and oxamyl. \% reduction in Helicotylenchus spp. after 5 months of treatment with composted animal manures (chicken, cow and sheep) and oxamyl were 41.20, 10.0, 19.63 and 48.37\%, respectively. A remarkable reduction in M.incognita numbers was illustrated with chicken, cow, sheep manures and oxamyl recording 40.69, 10.16, 16.09 and 45.68\% after 5 months of treatments, respectively. However, the percentages of reduction in Pratylenchus and Tylenchorhynchus population densities were 49.70\& 41.20; $13.53 \& 10.0 ; 22.17$ $\& 19.63$ and $46.73 \& 48.37$ after 5 months of application of chicken, cow, sheep and oxamyl, respectively.

In general, chicken manure showed the best performance in minified PPNs in grapevine fields followed by the treated nematicide, oxamyl and sheep manures in mostly applied fields while cow manure was the least effective one in this respect. 


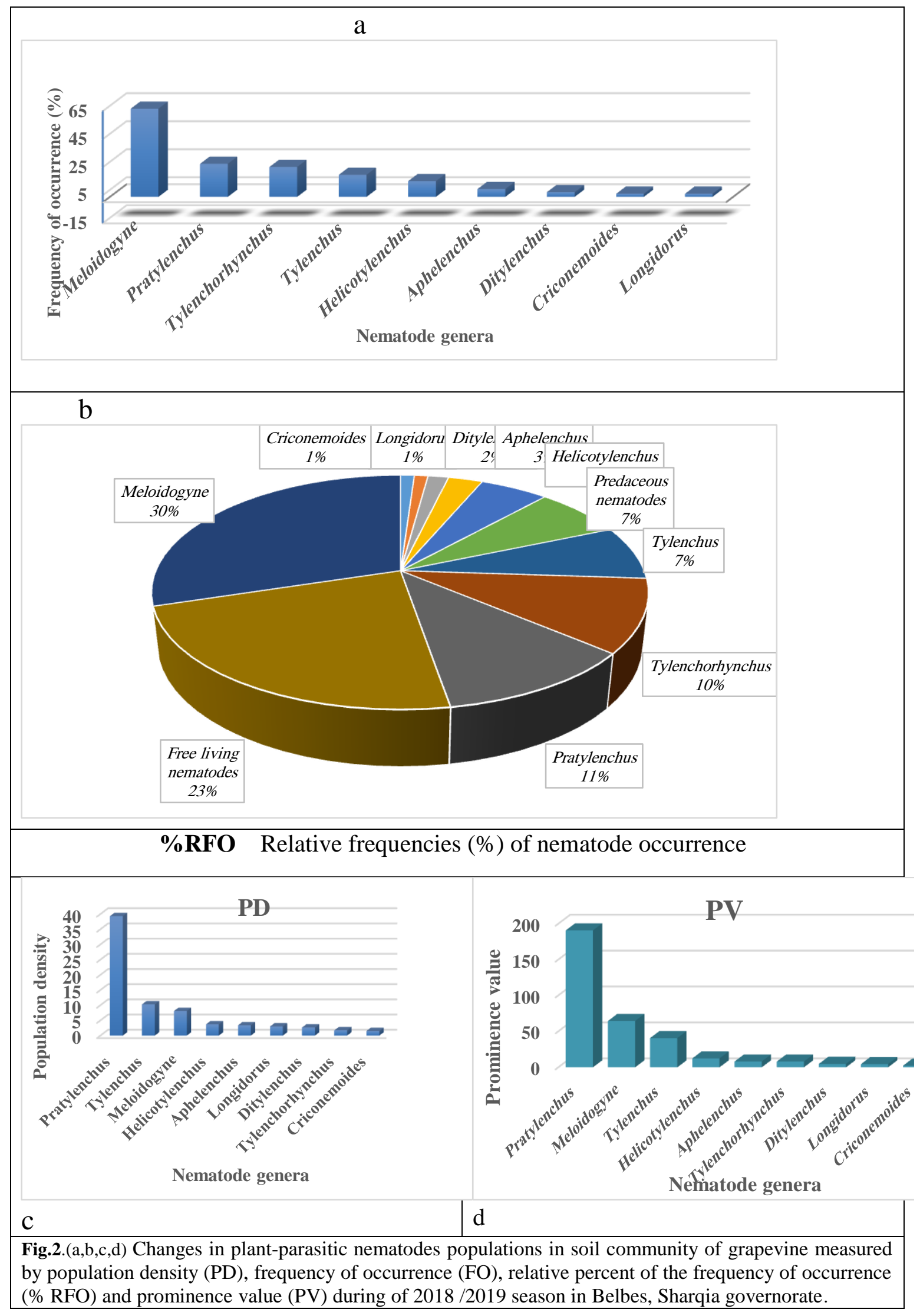




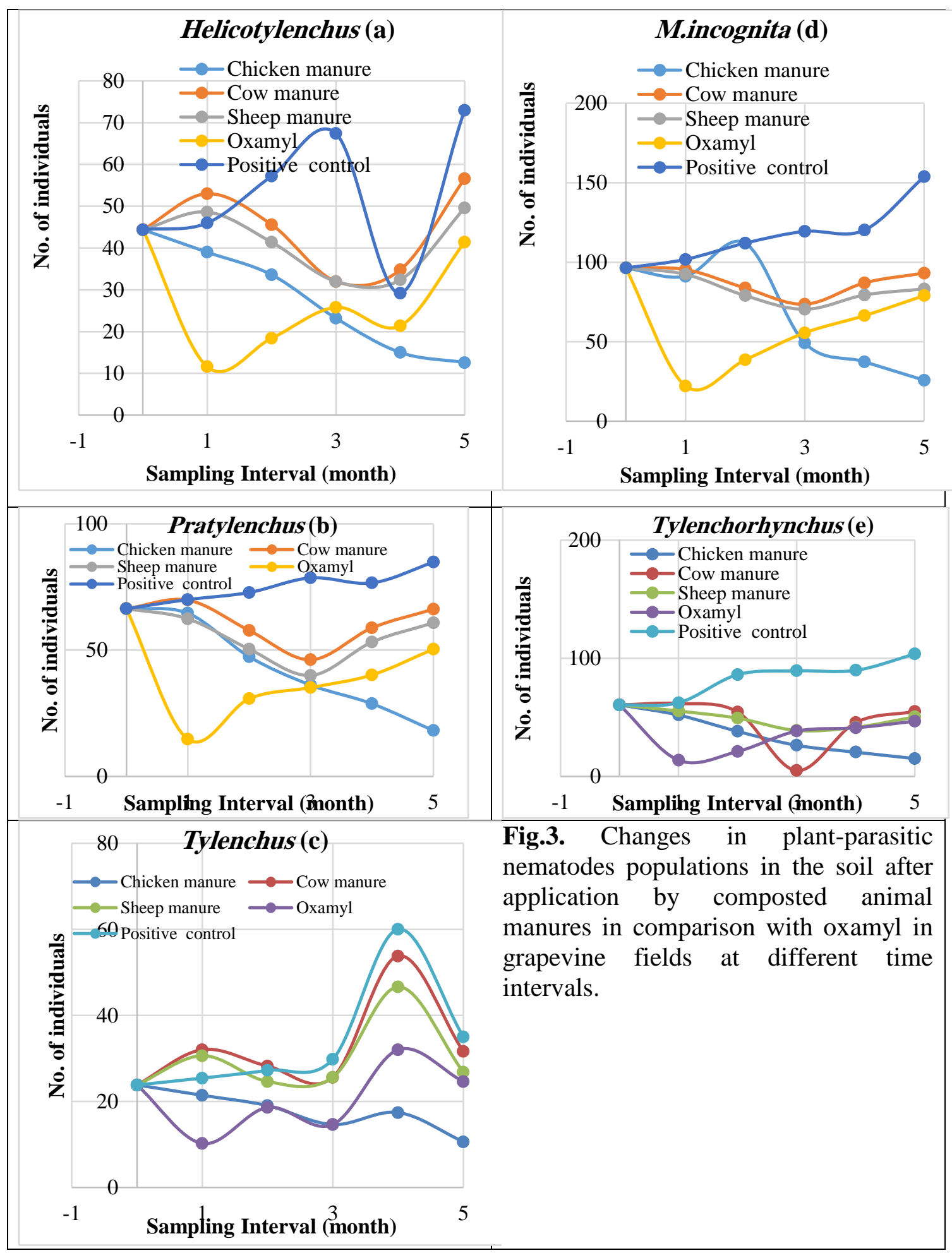




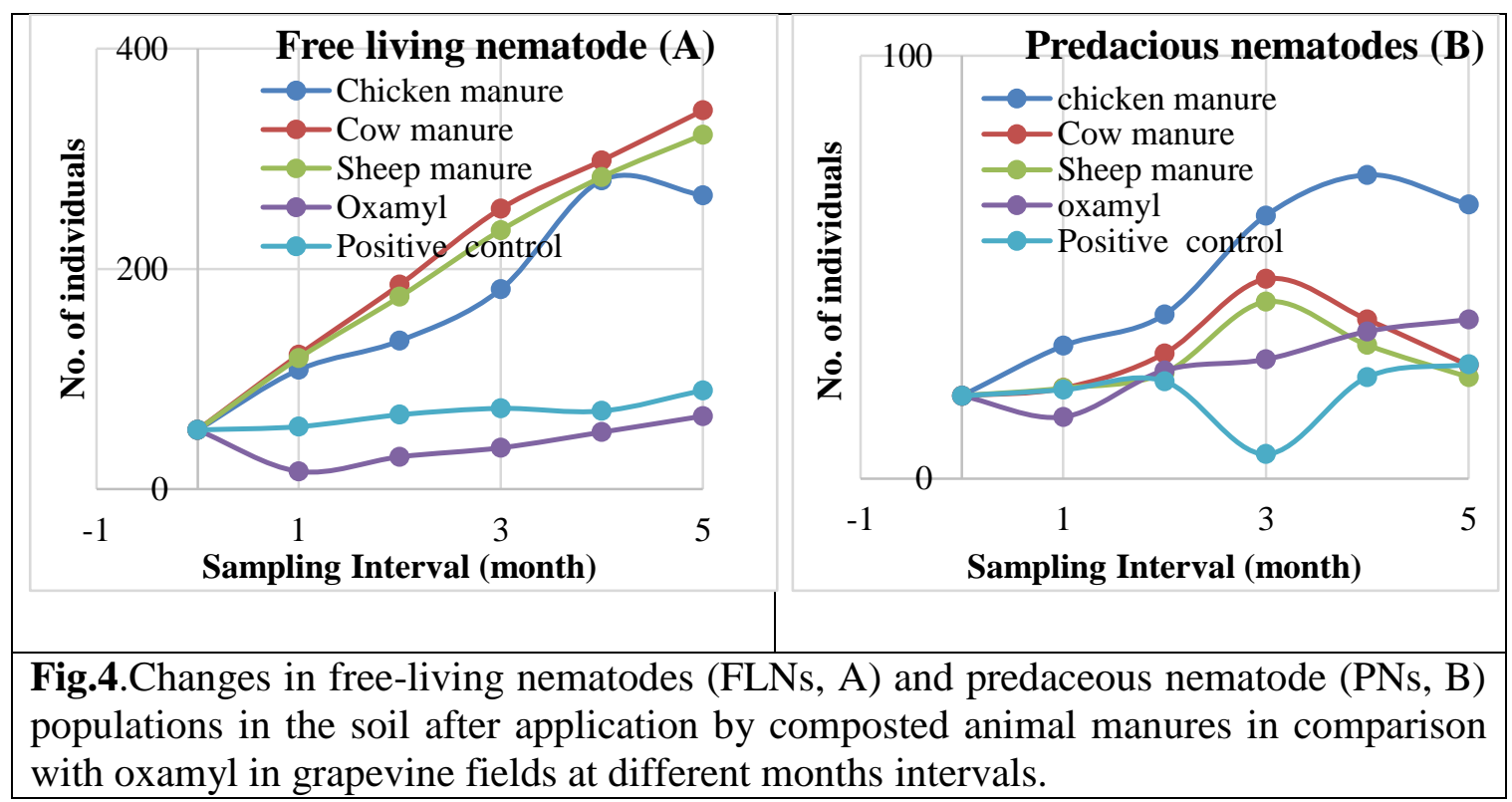

The efficiency of the three composted animal manures depends on total nitrogen (\%) and $\mathrm{C} / \mathrm{N}$ ratio. Total nitrogen (\%) was3.55, 1.57 and 1.09 in chicken, cow and sheep manure, respectively. As well as, the optimum $\mathrm{C} / \mathrm{N}$ ratio for soil microorganisms was found in chicken manure (11.6:1) besides extra contents of nitrogen content (3.55\%) were sufficient for microbial growth and plant requirements, followed by sheep manure (18.2: 1) and cow manure (26.4: 1). Although sheep manure shows a balanced proportion in most analysis parameters, sheep manure has the lowest nitrogen (1.09\%) content among the tested manures (Table 1).

\section{Plant growth, crop yields, nematode parameters and plant growth-promoting bacteria (PGPB) combined with animal manures:}

A positive association was recorded between grapevines parameters (plant growth, total fruit weight of vine), nematode parameters (free-living and predaceous nematodes) and composted animal manures applied alone or combined with rhizobacteria (Table3). All vines treated with tested materials significantly $(P \leq 0.05)$ decreased the number of M.incognita infective juveniles $/ 250 \mathrm{~g}$ soil. The combined applications of animal manures with rhizobacteria significantly reduced numbers of M.incognita $\mathrm{J}_{2}$ per 250/g soil, as compared with a single application, being rhizobacteria +chicken manure the most effective.

It is worth noting that numbers of FLNs and PNs/250g soil were significantly increased by all treatments (Table 3). The general mean of FLNs showed insignificant differences $(P \leq 0.05)$ among animal manures combined with rhizobacteria. Whereas, rhizobacteria +chicken manure sustained the highest number of PNs compared to other treatments. A significant improvement in vines plant growth and total fruit weight was indicated by all treatments, being the rhizobacteria + chicken manure the best (Table3). Moreover, leaf numbers/vine in treatments of combined rhizobacteria and animal manures were 313.20,267.00 and 302.00 with chicken, cow and sheep, respectively. A moderate leaf 
Table 2. Effects of composted animal manure application (chicken, cow and sheep manure) on nematode populations at different time intervals in soils of grapevine at the tested farm in 2019.

\begin{tabular}{|c|c|c|c|c|c|c|c|c|}
\hline \multirow[t]{2}{*}{ Nematode genus/species } & \multirow[t]{2}{*}{ Treatments } & \multicolumn{5}{|c|}{$\begin{array}{c}\text { Observation period } \\
\text { (month) }\end{array}$} & \multirow[t]{2}{*}{ Mean } & \multirow[t]{2}{*}{ Interaction } \\
\hline & & 1 & 2 & 3 & 4 & 5 & & \\
\hline \multirow{6}{*}{ Helicotylenchus } & Negative control & $46.60 \mathrm{~b}$ & $57.20 \mathrm{a}$ & $67.40 \mathrm{a}$ & $29.20 \mathrm{a}$ & $73.00 \mathrm{a}$ & 54.68 & \multirow[t]{6}{*}{$* *$} \\
\hline & Chicken manure & 39 & 33.6 & 23.2 & 15 & 12.6 & $24.68 \mathrm{c}$ & \\
\hline & Cow manure & 53 & 45.6 & 39.2 & 34.8 & 56.6 & $45.84 \mathrm{a}$ & \\
\hline & Sheep manure & 48.6 & 41.4 & 32 & 32.4 & 49.6 & $40.8 \mathrm{~b}$ & \\
\hline & Oxamyl & 11.6 & 18.4 & 25.8 & 21.4 & 41.4 & $23.72 \mathrm{c}$ & \\
\hline & Mean & $38.05 \mathrm{a}$ & $34.75 \mathrm{ab}$ & $30.05 \mathrm{~b}$ & $25.9 \mathrm{c}$ & $40.05 \mathrm{a}$ & & \\
\hline \multirow{6}{*}{ Meloidogyne incognita } & Negative control & $101.80 \mathrm{a}$ & $112.00 \mathrm{a}$ & $119.40 \mathrm{a}$ & $120.20 \mathrm{a}$ & $153.80 \mathrm{a}$ & 121.44 & \multirow[t]{6}{*}{$* *$} \\
\hline & Chicken manure & 91.2 & 82 & 49.2 & 37.4 & 25.8 & $57.12 \mathrm{c}$ & \\
\hline & Cow manure & 95.4 & 83.8 & 73.6 & 87 & 93.2 & $86.6 \mathrm{a}$ & \\
\hline & Sheep manure & 92.4 & 79 & 70.4 & 79.4 & 83.2 & $80.88 b$ & \\
\hline & Oxamyl & 22.2 & 38.6 & 55.6 & 66.4 & 79 & $52.36 \mathrm{~d}$ & \\
\hline & Mean & $75.3 \mathrm{a}$ & $70.85 b$ & $62.2 \mathrm{~d}$ & $67.55 \mathrm{c}$ & $70.3 \mathrm{bc}$ & & \\
\hline \multirow{6}{*}{ Pratylenchus } & Negative control & $70.00 \mathrm{a}$ & $72.80 \mathrm{a}$ & $78.60 \mathrm{a}$ & $76.60 \mathrm{a}$ & $84.80 \mathrm{a}$ & 61.24 & \multirow[t]{6}{*}{$* *$} \\
\hline & Chicken manure & 64.6 & 47.4 & 36.2 & 28.8 & 18.2 & $39.04 \mathrm{c}$ & \\
\hline & Cow manure & 69.8 & 57.8 & 46.2 & 58.8 & 66.2 & $59.76 a$ & \\
\hline & Sheep manure & 62.4 & 50.4 & 40 & 53.2 & 60.8 & $53.36 \mathrm{~b}$ & \\
\hline & Oxamyl & 14.8 & 30.8 & 35.2 & 40.2 & 50.4 & $34.28 \mathrm{~d}$ & \\
\hline & Mean & $52.9 \mathrm{a}$ & $46.6 \mathrm{~b}$ & $39.4 \mathrm{c}$ & $45.25 \mathrm{~b}$ & $48.9 \mathrm{~b}$ & & \\
\hline \multirow{6}{*}{ Tylenchorhynchus } & Negative control & $62.40 \mathrm{a}$ & $86.20 \mathrm{a}$ & $89.40 \mathrm{a}$ & $89.80 \mathrm{a}$ & $103.60 \mathrm{a}$ & 86.28 & \multirow[t]{6}{*}{$* *$} \\
\hline & Chicken manure & 52 & 38.2 & 26.4 & 20.6 & 15.2 & $30.48 \mathrm{c}$ & \\
\hline & Cow manure & 61.8 & 54.6 & 45 & 45.6 & 55 & $52.4 \mathrm{a}$ & \\
\hline & Sheep manure & 55.4 & 49.4 & 39 & 41.6 & 50.4 & $47.16 \mathrm{~b}$ & \\
\hline & Oxamyl & 13.8 & 21.2 & 38.4 & 41.2 & 46.8 & $32.28 \mathrm{c}$ & \\
\hline & Mean & $45.75 \mathrm{a}$ & $40.85 b$ & $37.2 \mathrm{c}$ & $37.25 \mathrm{c}$ & $41.85 \mathrm{~b}$ & & \\
\hline \multirow{6}{*}{ Tylenchusspp. } & Negative control & $25.40 \mathrm{~b}$ & $27.20 \mathrm{a}$ & $29.80 \mathrm{a}$ & $60.00 \mathrm{a}$ & $35.00 \mathrm{a}$ & 35.48 & \multirow[t]{6}{*}{$* *$} \\
\hline & Chicken manure & 21.4 & 19 & 14.6 & 17.4 & 10.6 & $16.6 \mathrm{~d}$ & \\
\hline & Cow manure & 32 & 28.2 & 25.6 & 53.8 & 31.6 & $34.24 \mathrm{a}$ & \\
\hline & Sheep manure & 30.6 & 24.6 & 20.8 & 46.6 & 26.8 & $29.88 b$ & \\
\hline & Oxamyl & 10.2 & 18.6 & 14.6 & 32 & 24.6 & $20.0 \mathrm{c}$ & \\
\hline & Mean & $23.55 b$ & $22.6 b c$ & $18.9 \mathrm{c}$ & $37.45 \mathrm{a}$ & $23.4 \mathrm{~b}$ & & \\
\hline \multirow{6}{*}{ Free-living nematodes } & Negative control & $56.80 \mathrm{c}$ & $67.60 \mathrm{~d}$ & $73.40 \mathrm{~d}$ & $71.00 \mathrm{c}$ & $89.80 \mathrm{c}$ & $71.72 d$ & \multirow[t]{6}{*}{$* *$} \\
\hline & Chicken manure & 122 & 185.8 & 254.8 & 298.6 & 344 & $239.24 \mathrm{a}$ & \\
\hline & Cow manure & 108.4 & 134.8 & 181.6 & 280.6 & 267 & $194.48 \mathrm{c}$ & \\
\hline & Sheep manure & 119 & 174.8 & 235.2 & 283.6 & 322 & $226.92 \mathrm{~b}$ & \\
\hline & Oxamyl & 16.2 & 29.4 & 37.6 & 51.8 & 66.4 & $40.28 \mathrm{~d}$ & \\
\hline & Mean & $91.4 \mathrm{e}$ & $131.2 \mathrm{~d}$ & $177.3 \mathrm{c}$ & $228.65 b$ & $249.85 \mathrm{a}$ & & \\
\hline \multirow{6}{*}{ Predacious nematodes } & Negative control & $21.00 \mathrm{~b}$ & $23.00 \mathrm{c}$ & $25.80 \mathrm{c}$ & $24.00 \mathrm{c}$ & $27.00 \mathrm{c}$ & 24.16 & \multirow[t]{6}{*}{$* *$} \\
\hline & Chicken manure & 31.4 & 38.8 & 62.2 & 71.8 & 64.8 & $53.8 \mathrm{a}$ & \\
\hline & Cow manure & 21.4 & 25 & 41.8 & 31.6 & 24 & $28.76 \mathrm{c}$ & \\
\hline & Sheep manure & 21.4 & 29.6 & 47.2 & 37.6 & 26.8 & $32.52 b$ & \\
\hline & Oxamyl & 14.6 & 25.6 & 28.2 & 34.8 & 37.6 & $28.16 c$ & \\
\hline & Mean & $22.2 \mathrm{~d}$ & $29.75 c$ & $44.85 a$ & $43.95 a$ & $38.3 \mathrm{~b}$ & & \\
\hline
\end{tabular}

Interactions among factors were significant at $95 \%$ confidence.

* Means followed by the same letter for a given factor in a column are not significantly different based on Tukey's HSD test at $95 \%$ confidence. 
Table 3.Effect of composted animal manures (chicken, cow and sheep manures) alone or combined with rhizobacteria (PGPB) on grapevine plants and nematode parameters at harvesting time.

\begin{tabular}{|c|c|c|c|c|c|}
\hline \multirow[b]{2}{*}{ Treatments } & \multicolumn{3}{|c|}{ Nematode parameters } & \multicolumn{2}{|c|}{ Grapevine parameters } \\
\hline & $\begin{array}{l}\text { M.incognita } \\
\mathrm{J}_{2} / 250 \text { g soil }\end{array}$ & $\begin{array}{c}\text { Free-living } \\
\text { nematodes/ } \\
250 \mathrm{~g} \text { soil }\end{array}$ & $\begin{array}{l}\text { Predacious } \\
\text { nematodes } \\
/ 250 \mathrm{~g} \text { soil }\end{array}$ & $\begin{array}{c}\text { Leaf } \\
\text { numbers/ } \\
\text { vine }\end{array}$ & $\begin{array}{l}\text { Total fruit } \\
\text { weight/ } \\
\text { vine } / \mathrm{kg}\end{array}$ \\
\hline Control (untreated) & $59.54^{\mathrm{a}}$ & $59.54^{\mathrm{c}}$ & $7.20^{\mathrm{e}}$ & $54.60^{\mathrm{e}}$ & $2.12^{\mathrm{g}}$ \\
\hline Rhizobacteria + chicken manure & $1.55^{\mathrm{f}}$ & $72.30^{\mathrm{a}}$ & $16.15^{\mathrm{a}}$ & $313.20^{\mathrm{a}}$ & $16.15^{\mathrm{a}}$ \\
\hline Rhizobacteria + cow manure & $8.70^{\mathrm{c}}$ & $68.40^{\mathrm{a}}$ & $14.05^{\mathrm{bc}}$ & $267.00^{\mathrm{c}}$ & $10.87^{\mathrm{c}}$ \\
\hline Rhizobacteria + sheep manure & $3.70^{\mathrm{e}}$ & $69.10^{\mathrm{a}}$ & $14.30^{\mathrm{b}}$ & $302.00^{\mathrm{b}}$ & $13.53^{\mathrm{b}}$ \\
\hline Chicken manure & $5.45^{\mathrm{d}}$ & $69.80^{\mathrm{a}}$ & $15.18^{\mathrm{a}}$ & $271.40^{\mathrm{bc}}$ & $9.19^{d}$ \\
\hline Cow manure & $14.10^{\mathrm{b}}$ & $60.70^{b}$ & $12.45^{\mathrm{d}}$ & $218.20^{\mathrm{d}}$ & $5.83^{\mathrm{f}}$ \\
\hline Sheep manure & $8.95^{\mathrm{c}}$ & $61.65^{\mathrm{b}}$ & $12.65^{\mathrm{d}}$ & $265.40^{\mathrm{c}}$ & $6.57^{\mathrm{e}}$ \\
\hline Oxamyl & $3.20^{\mathrm{e}}$ & $51.40^{c}$ & $6.30^{\mathrm{e}}$ & $251.40^{\mathrm{cd}}$ & $9.10^{\mathrm{d}}$ \\
\hline
\end{tabular}

*Each value is the mean of five replicates.

*Means followed by the same letter in the same column do not differ significantly according to Duncan's Multiple Range Test $(P \leq 0.05)$

number/vine was achieved in treatments of chicken (271.40), cow (218.20) and sheep (265.40), respectively compared with 54.60 in the control treatment. Generally, it could be concluded that treated grapevine with rhizobacteria enhanced plant growth (leaf numbers) and increased vine crop yield (total fruit weight) and support sustainable numbers of FLNs and PNs as well as, diminished numbers of M.incognita/250g soil.

\section{DISCUSSION}

A survey of plant-parasitic nematodes, free-living (FLNs) and predaceous nematodes (PNs) conducted in grapevine plantations revealed the highest population of Pratylenchus, Tylenchus, Meloidogyne and Helicotylenchus while the lowest population densities occurred with genera Aphelenchus, Longidorus, Ditylenchus, Tylenchorhynchus, Tylenchulus and Criconemoides. The highest relative frequencies (\%) of nematode occurrence (RFO \%) were determined and exhibited. The root-knot nematode, Meloidogyne (29.32\%) exhibited the highest relative frequencies of nematode occurrence (RFO \%), followed by Pratylenchus (10.99\%) and Tylenchorhynchus (9.946\%). These findings are in agreement with those reported by Rubiano and Agudelo (1995) who conducted a survey in grapevine grown in the Cauca Valley, Colombia and revealed the presence of six genera arranged in descending order.

In the current study, chicken, cow and sheep manure were applied alone or combined with commercial rhizobacteria as curative treatments on grapes infected with $M$. incognita. It is the first time to discuss the effects of fertilizing with animal manure alone or combined with bioagents in controlling PPNs and changes in other associated freeliving and predaceous nematodes under field conditions in grapevine orchard Treatments particularly rhizobacteria +chicken manure significantly $(P \leq 0.05)$ reduced the number 
of $\mathrm{J} 2 / 250 \mathrm{~g}$ soil and increased grapevine growth (number of leaves and total fruit yield/vine) followed by sheep and cow manures combined with rhizobacteria compared to the untreated control. As well as free-living and predacious nematodes were detected in high proportions in soils of livestock animal manures and plant growth-promoting bacteria (PGPB). Stimulation of bacterivores and predators nematodes following amendment addition was observed (McSorley ,2011; Yang et al., 2016; El-Marzoky et al., 2018). The combination between PGPB and composted animal manure particularly composted chicken manure under field conditions enhanced plant growth of vegetable and banana plants and low-cost successful tools to use in place of chemical nematicides (El-Ashry et al., 2020). Organic amendments when used with Bio nema increased plant growth, cluster weight and total fruit yield (El-Sheikh et al., 2006).

Current physical and chemical analysis of chicken, cow and sheep manures revealed high percent of organic matter $(68.19,68.36$ and 67.85 , respectively), organic carbon (39.62,39.69 and 38.66, respectively), phosphorus $(0.73,0.41$ and 0.42 , respectively), $\mathrm{pH}$ (8.41,9.32 and 7.95, respectively) and $\operatorname{NPK}(1.1: 0.8: 0.5 ; 0.6: 0.4: 0.5$ and $0.7: 0.3: 0.9)$ (Table 1). In temperate and forest soils, several manure components like organic carbon (C), $\mathrm{pH}$, and water play determined factors in the distribution of soil nematodes (Liu et al., 2019). Manures are claimed to improve plant growth by providing nutrients, stimulating growth, enhancing flowering and fruiting, increasing beneficial microbes and controlling diseases and pests (Stewart-Wade, 2020).

Adding fertilizer to the soil enhanced soil physical and biological properties and has a disease suppression effect (Larney et al., 2006). The soil with high organic matter shower high biodiversity variability (Liu et al., 2016). Amending the soil with organic matter improved soil physical properties and nutrient concentrations without increasing nutrient runoff (Johnson et al., 2006). Also, soil chemical properties e.g., salt content, pH, and simple obstacle tool against harmful soil fauna species in healthy soil. The nematicidal effects of organic additives depend on their chemical compositions and the composition and such as $\mathrm{C}: \mathrm{N}$ ratio and activity of the decomposer community that develops during degradation (Rodriguez-Kabana et al., 1986\& 1987).

Soil fauna including free-living nematode populations and bacteria are inversely related to root-knot nematode $M$. incognita density (Chen et al., 1994) contribute to the decomposition of organic soil amendments and mineralization of nitrogen and phosphorus with an indirect beneficial effect on plant growth (De Mesel et al., 2006). Decomposing manure by microbial activity releases the suppressed and toxic ammoniacal nitrogen for phytonematode populations. As a result of the decomposition of organic matter by abundant soil fauna, their activities caused the release of ammonia, nitrites, hydrogen sulfide, organic acids, and other volatile chemicals that can directly nematicidal or affect egg-hatch, or the motility of juveniles (Khatamidoost et al., 2015; Zhai et al., 2018).

All rhizobacteria can produce at least one antibiotic (Ludwig et al., 2013) and other types of toxicity include ammonia, hydrogen cyanide, and sulfide liberation (CastanedaAlvarez and Aballay, 2016; El-Rahman et al., 2019). Due to this reason, synergistic interaction between rhizobacteria combinations surpassing apply each of them separately (Anwar-ul-Haq et al., 2011; Majzoob et al., 2012; RunJin et al., 2012). 
Burkett-Cadena et al. (2008) showed that integration of composted animal manures and PGPB increased rhizosphere bacterial populations with suppressing RKN nematodes and without necessarily enhancing soil microbial periodically. As well as, degradable enzymes e.g. chitinases, phosphatases, lipases, collagenase, gelatinase, and proteinase besides releasing siderophores in the rhizosphere (Castaneda-Alvarez and Aballay, 2016; Ludwig et al., 2013; Safni et al., 2018).

Plant growth-promoting bacteria (PGPB) have the potency to increase plant growth parameters and decrease nematode reproduction. A previous study by El-Ashry et al. (2020) illustrated that the efficiency of PGPB is related to inoculum density and application rates under field conditions in banana fields and suitable latent periods after inoculation. Moreover, PGPB reduced the reproduction of root-knot nematodes by minimization of the number of egg masses, galls and numbers of $\mathrm{J}_{2}$ in treated soils. Moreover, integrated use of organic manures (FYM) improving soil health, nutrient uptake and maintainable crop production (Sharma et al., 2020).

The positive effect of manure application on grapevine yield might be due to the increase in the storage of soil organic carbon (SOC), soil nutrient contents, and $\mathrm{pH}$ (Cai et al., 2019). So, after treatment of composted animal manures with high concentrations of $\mathrm{N}$, the richness of bacterivorous nematodes was observed (Shaw et al., 2019) as a result of tight linkages with microbial and plant activities. The $\mathrm{C} / \mathrm{N}$ ratio of 15-20 is optimal for the soil microorganisms when amendments are added to a 1\% level (Osunlola \&Fawole, 2015).

Although the study did not investigate the interaction with other soil fauna and nematodes, enhanced vine plant growth and its fruit yield after amended with animal manure and applied rhizobacteria due to enhancement in tree nutrient uptake. So, other abiotic factors and biotic factors might be affected indirectly on soil ecology and alter microbial biomass via alterations in nematode activities.

\section{CONCLUSION}

Farmer-friendly practices for the management of phytoparasitic (plant-parasitic nematodes (PPNs), particularly root-knot nematodes and promoting of free-living, FLNs and predacious nematodes, PNs have been assessed in the current study by application of three composted (chicken, cow and sheep) manures as natural sources for controlling phytophagous nematodes mainly $M$. incognita in combination with novel rhizobacteria (PGPB) products in vines fields. Recent results proved that suppressive strategies might be used animal manures combined with rhizobacteria as effective eco-friendly tools for managing the diversity of the nematode communities rather than curative treatments in controlling plant-parasitic nematodes and have the worthy performance for increasing plant growth and fruit yield grapevines fields. So, these ancient practices could be recommended in Egyptian fields and improved by the application of PGPB for organic farms a better option in the management of PPNs programs as well as, maybe successful tools to use in place of chemical nematicides in heavily infested fields. 


\section{REFERENCES}

Akhtar, M. and M.M. Alam (1993). Control of plant-parasitic nematodes by 'Nimin'-an urea coating agent and some plant oils. Zet. F. Pl. tn. und Pf., 10: 337-342.

Anwar-ul-Haq, M.; Anwar, S.A.; Shahid, M.; Javed, N.; Khan, S.A. and Mehamood, K.(2011). Management of root knot nematode Meloidogyne incognita by plant growth promoting rhizobacteria on tomato. J.Zool. ,43:1027-1031.

Bhusal, D.R. k.; AllimAnis, A.S.; Tsiafouli, M.A. and Sgardelis, S.P.(2014).Higher taxa vs. functional guilds vs. trophic groups as indicators of soil nematode diversity and community structure. Ecol.Indic., 41: 25 - 29.

Burkett-Cadena, M.; Kokalis-Burelle, N.; Lawrence, K.S.; Santen, E. van and Kloepper, J.W. (2008). Suppressiveness of root-knot nematodes mediated by rhizobacteria. Biol. Control, 47:55-59.

Cai, P.; Sun, X.; Wu, Y.; Gao, C.; Mortimer, M.; Holden, P. A. and Huang, Q. (2019). Soil biofilms: microbial interactions, challenges, and advanced techniques for exsitu characterization. Soil Ecology Letters, 1-9.

Castaneda-Alvarez, C. and Aballay, E. (2016). Rhizobacteria with nematicide aptitude: enzymes and compounds associated.World J.Microbiol., 32(12):1-7.

Castaneda-Alvarez, C.; Prodan, S.; Rosales, I.M. and Aballay, E.(2016). Exoenzymes and metabolites related to the nematicidal effect of rhizobacteria on Xiphinema index Thorne \& Allen. J.Applied Microbiol., 120: 413-424.

Chen, S.; Dickson, D.W.; Kimbrough, J.W.; McSorley, R. and Mitchell, D.J. (1994). Fungi associated with females and cysts of Heterodera glycines in a Florida soybean field. J.Nematol., 26, 296.

De Mesel, I.; Derycke, S.;Swings, J.; Vincx, M. and Moens, (T.) 2006. Role of nematodes in decomposition processes: Does within-trophic group diversity matter? Mar. Ecol. Prog. Ser., 321: 157-166.

De Vries, F.T.;Thebault, E.; Liiri, M.;Birkhofer, K.;Tsiafouli, M.A.;Bjornlund, L.;Bracht Jorgensen, H.; Brady, M.V.; Christensen, S.;de Ruiter, P.C.;d'Hertefeldt, T.;Frouz, J.;Hedlund, K.;Hemerik, L.; Hol, W.H.G.;Hotes, S.;Mortimer, S.R.; Setala, H.;Sgardelis, S.P.;Uteseny, K.; van der Putten, H.;Wolters, V. and Bardgett, R.D. (2013). Soil food web properties explain ecosystem services across European land use systems. Proc. Natl. Acad. Sci., 110:14296-14301.

El-Ashry, R. M.;Abdelhadi A. I. Ali and Salonaz E. Awad (2020). Enhancing application efficiency of Pseudomonas SPP. and Serratia marcescens isolates against Meloidogyne incognita in tomato plants. Egypt. Acad. J. Biol. Sci., 12(2): 127-145.

El-Gendy, Rafaat S.S. and Shawky, Samaa M. (2006). Efficacy of some natural plants and bioagents to minimize the population of root knot nematode; Meloidogyne incognita in superior seedless vineyards and its reflection on vine growth and yield. 1st International Egyptian-Jordanian Conference on Biotechnology and Sustainable Development: Current Status and Future Scenarios, pp. 264-280.

El-Marzoki A. M.; Eldeeb, A.M. ; El-Ashry, R. M.and Mahrous,M.E.(2018). Influence of certain animal manures on nematode community in mandarin orchards Citrus reticulata (Blanco) in Sharkia Governorate, Egypt. Egypt. J. Agronematol.,17(2): 143-157. 
El-Rahman, A.F.A.; Shaheen, H.A.; El-Aziz, R.M.A. and Ibrahim, D.S.S. (2019). Influence of hydrogen cyanide-producing rhizobacteria in controlling the crown gall and root-knot nematode, Meloidogyne incognita. J.Biol. Pest Control 29.

El-Sheikh, M. H.; El-Motty, E. Z.A and Hasabo, S. A. A. (2006).Effect of two organic amendments, elemental sulphur, bionema and carbofuran soil application to control root-knot nematode on growth and productivity of Thompson Seedless grapes. Am Eurasian J Agric Environ Sci.,1(3):191-197.

Ferris, H. and Tuomisto, H. (2015).Unearthing the role of biological diversity in soil health. Soil Biol. Biochem. , 85: 101-109.

Geisseler, D. and Scow, K.M. (2014).Long-term effects of mineral fertilizers on soil microorganisms-a review. Soil Biol. Biochem. ,75:54-63.

Giné, A.; Carrasquilla, M.; Martínez-Alonso, M.; Gaju, N. and Sorribas, F.J. (2016). Characterization of soil suppressiveness to root-knot nematodes in organic horticulture in plastic greenhouse. Front. Plant Sci., 7: 1-15.

Hassen, A., Belguith, K., Jedidi, N., Cherif, M., Boudabous, A., 2001. Microbial characterization during composting of municipal solid waste. Bioresour. Technol., 80:217-225.

Hopper, D.J.; Hallmann, J. and Subbotin, S.A. (2005).Methods of extraction, processing and detection of plant and soil nematodes.Pp 53-84. In: Plant Parasitic Nematodes in Subtropical and Tropical Agriculture, Eds: M. Luc; A.R. Sikora and J. Bridge, 2 Edition, CAB International, Wallingford, UK, 871pp.

Johnson, G.A.; Davis, J.G.; Qian, Y.L. and Doesken, K.C. (2006). Topdressing Turf with Composted Manure Improves Soil Quality and Protects Water Quality. Soil Sci.Soc. Am. J., 70: 2114-2121.

Kepenekci, I., Selcuk, H. and Lewism E. E. (2016). Evaluation of entomopathogenic nematodes and the supernatants of the in vitro culture medium of their mutualistic bacteria for the control of the root-knot nematodes Meloidogyne incognita and $M$. arenaria. Pest Manag. Sci., 72(2): 327-334.

Kesba, H.H. (1999). Ecological and pathological studies on some plant parasitic nematodes infecting grape, Vitis vinifera L., M.Sc., Thesis. Fac. Agric., Cairo Univ., Egypt, p. 23.

Khatamidoost, Z.; Jamali, S.; Moradi, M. and Saberi Riseh, R. (2015). Effect of Iranian strains of Pseudomonas spp. on the control of root-knot nematodes on Pistachios. Biocontrol Sci. Technol., 25: 291-301.

Larney, F.J.; Sullivan, D.M.; Buckley, K.E. and Eghball, B. (2006). The role of composting in recycling manure nutrients. Canadian J. Soil Sci., 86: 597-611.

Leege, P.B. and Thompson, W.H. (1997). Test methods for the examination of composting and compost. U.S. Composting Council, Bethesda, Md.

Lemunier, M.; Francou, C.; Rousseaux, S.; Houot, S.; Dantigny, P.; Piveteau, P. and Guzzo, J.(2005). Long-term survival of pathogenic and sanitation indicator bacteria in experimental biowaste composts. Applied Environ. Microbiol.,71: 5779-5786.

Liu, T.; Chen, X.; Hu, F.; Ran, W.; Shen, Q.; Li, H. and Whalen, J.K. (2016). Carbonrich organic fertilizers to increase soil biodiversity: Evidence from a meta-analysis of nematode communities. Agric. Ecosyst. Environ. , 232: 199-207.

Liu, T.; Hu, F. and Li, H. (2019). Spatial ecology of soil nematodes: perspectives from global to micro scales. Soil Biol. Biochem., 137: 107565. 
Ludwig, J.; Moura, A.B. and Gomes, C.B.(2013). Potential of microbiolization of rice seeds with rhizobacteria for root-knot nematode biocontrol. Trop.Plant Pathol.,38: 264-268.

Mai, W.F. and Lyon, H.H. (1975). Pictorial key to genera of plant parasitic nematodes. Cornell Univ. Press, Ithaca, New York, 219 pp.

Majzoob, S.; Karegar, A.; Taghavi, M. and Hamzehzarghani, H.(2012). Evaluation of rhizobacteria for antagonistic activity against root-knot nematode, Meloidogyne javanica on cucumber, under greenhouse condition. Iran.J.Plant Pathol.,48(1):2729.

Mc Carter, J.P.(2008). Nematology: terra incognita no more. Nat. Biotechnol. 26: 882-4.

McSorley,R.(2011) Overview of organic amendments for management of plant-parasitic nematodes, with case studies from Florida.J.Nematol.,43(2):69-81.

Neher, D.A. (2001). Role of nematodes in soil health and their use as indicators, J. Nematol.,33:161-168.

Nicholson, F.A.; Groves, S.J. and Chambers, B.J. (2005). Pathogen survival during livestock manure storage and following land application. Bioresour Technol., 96: 135-43.

Norton, D.C. (1978). Some simple methods of community analysis. Pp.66-68, In: Ecology of plant-parasitic nematode. John Wiley, Sons. Inc. 268 pp.

Omar Shaza and Olutayo O. Akingbe (2020). Overview of Egypt's Table Grape Sector (Report Number:EG2020-0055) by USDA Foreign agriculture service.

Osman, H. A.; Ameen, H. H.; Mohamed, M.; El-Mohamedy, R. and Elkelany, U. S. (2018). Field control of Meloidogyne incognita and root rot disease infecting eggplant using nematicide, fertilizers, and microbial agents. Egypt. J.Biol. Pest Control, 28(1): 40.

Osunlola, O.S. and Fawole, B. (2015). Evaluation of animal dungs and organomineral fertilizer for the control of Meloidogyne incognita on sweet potato. Inter. J. Agron. 5 pp. https: doi.org/10,115/2015/725363.

Rodriguez-Kabana, R. (1986). Organic and inorganic nitrogen amendments to soil as nematode suppressants. J.Nematol., 18: 129.

Rodriguez-Kabana, R.; Morgan-Jones, G. and Chet, I. (1987). Biological control of nematodes: Soil amendments and microbial antagonists. Plant Soil,100: 237-247.

Rubiano, J. A. and Agudelo, F. V. de. (1995). Identification and parasitism of nematodes of grape Vitis spp. Fitopatologia Colombiana, 19 (2):27-35.

RunJin, L., Mei; D., Xia, W.; Min, L.; XingZhong, L.(2012). Suppression of the rootknot nematode [Meloidogyne incognita (Kofoid \& White) Chitwood] on tomato by dual inoculation with arbuscular mycorrhizal fungi and plant growth-promoting rhizobacteria. Mycorrhiza, 22: 289-296.

Safni, I., Lisnawita Lubis, K.; Tantawi, A.R.and Murthi, S.(2018). Isolation and characterization of rhizobacteria for biological control of root-knot nematodes in Indonesia. Journal of the International Society for Southeast Asian Agricultural Sciences, 24: 67-81.

Schneider, S.M.; Rosskopf, E.N.; Leesch, J.G.; Chellemi, D.O.; Bull, C.T. and Mazzola, M. (2003). Research on alternatives to methyl bromide: pre-plant and post-harvest. Pest Manag. Sci., 59: 814-826. 
Sharma, N.; Shukla, Y. R.; Singh, K. and Mehta, D. K. (2020). Soil fertility, nutrient uptake and yield of bell pepper as influenced by conjoint application of organic and inorganic fertilizers. Commun. Soil Sci. Plant Anal., 51(12):1626-1640.

Shaw, G. T. W.; Weng, C. Y.; Chen, C. Y.; Weng, F. C. H., and Wang, D.(2019). A systematic approach re-analyzing the effects of temperature disturbance on the microbial community of mesophilic anaerobic digestion. Scientific reports 9(1):114.

Siddiqi, M.R. (1986). Tylenchida, parasites of plants and insects. C.A.B. Commons. Inst. Parasit.; Slough, UK, 645 pp.

Stewart-Wade, S. M. (2020). Efficacy of organic amendments used in containerized plant production: Part 1 - Compost-based amendments. Scientia Horticulturae, 266.

Sukul, N.C. (1992). Plant antagonistic to plant-parasitic nematodes. Indian Rev. of L. Sci., 12: 23-52.

Yang, L.; Huang, B.;Mao, M.; Yao, L.; Niedermann, S.; Hu, W. and Chen, Y. (2016). Sustainability assessment of greenhouse vegetable farming practices from environmental, economic, and socio-institutional perspectives in China. Environ. Sci. Pollut. Res., 23:17287-17297.

Yeates, G.W. and Coleman, D.C. (1982). Nematodes in decomposition, in: D.W. Freckman (Ed.), Nematodes in Soil Ecosystems, University of Texas Press, Austin, pp. 55-80.

Yeates, G.W.; Bongers, T.; De Gloede, R.G.; Freckman, D.W. and Georgieva, S.S., 1993.Feeding habits in soil nematode families and genera-an outline for soil ecologists. J.Nematol., 25: 315-331.

Zasada, I.A.; Halbrendt, J.M.; Kokalis-Burelle, N.; LaMondia, J.; McKenry, M.V. and Noling, J.W.(2010). Managing nematodes without methyl bromide. Annua. Revue Phytopathol., 48: 311-328.

Zhai, Y.; Shao, Z.; Cai, M.; Zheng, L.; Li, G.; Huang, D.; Cheng, W.; Thomashow, L.S.; Weller, D.M.; Yu, Z. and Zhang, J. (2018). Multiple modes of nematode control by volatiles of Pseudomonas putida 1A00316 from Antarctic Soil against Meloidogyne incognita. Front Microbiol., 9:253-253. 


\title{
الملخص العربي
}

\section{إستخدم المخلفات الحيوانية مع بكتيريا المجال الجذرى كأدوات فعالة للسيطرة علي أعداد نيماتودا

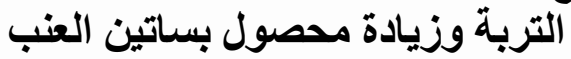

\author{
رمضان محمد أحمد العشري

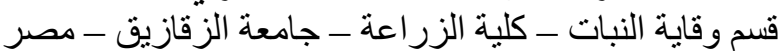

كثف الحصر الذى أجرى لمجنمع النيماتودا في حقول العنب عن تسعة أجناس من النيماتودا المنطفلة على النبات

Aphelenchus 'Criconemoides ، Ditylenchus ، Helicotylenchus ، Longidorus ،

Meloidogyne ‘ Pratylenchus ، Tylenchus g Tylenchorhynchus

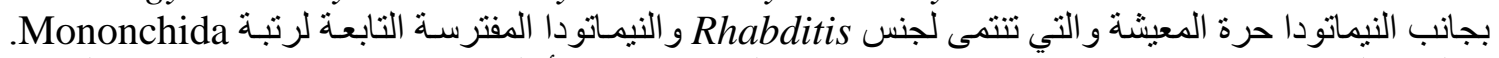

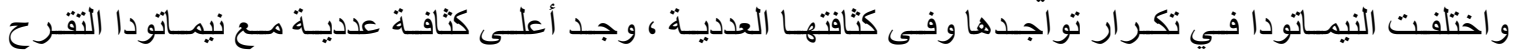
Pratylenchus يليها كل من جنس Helicotylenchus و وكان جنس نيماتودا

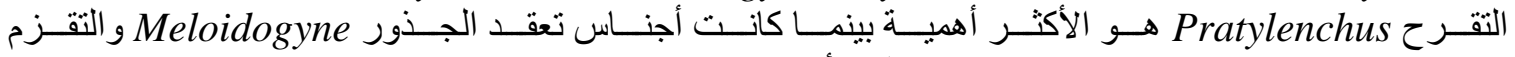

Tylenchus و Tylenchynchus

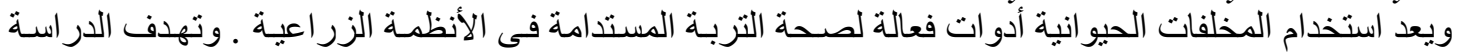

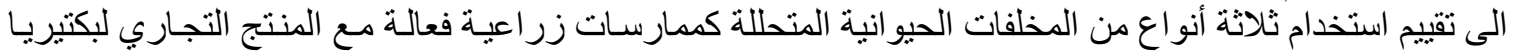

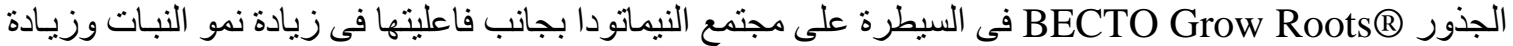
ثمار محصول العنب .Vitis vinifera L صنف فليم حيث أخذت العينات خلال 5 فترات زمنية.

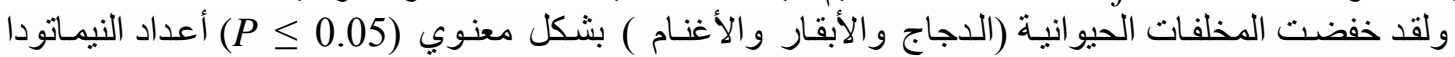
المتطفلة على النبات.

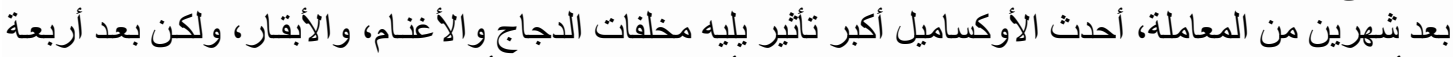

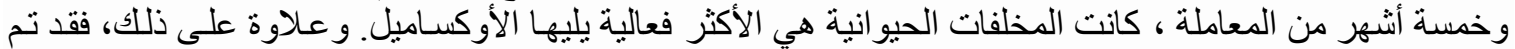

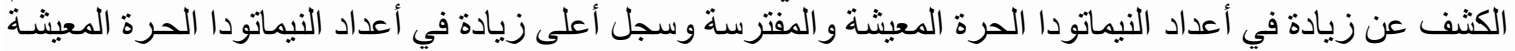

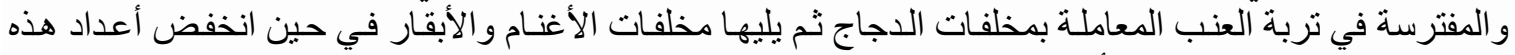

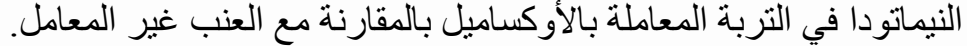

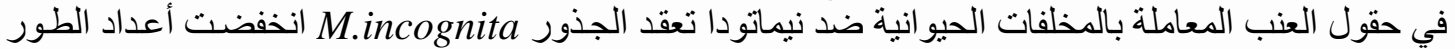
اليرقي الثاني/250 جر ام تربة في حقول العنب المعاملة بكل من مخلفات الدجاج و الأبقار و الأغنام على التو الي، و إلى الى التى

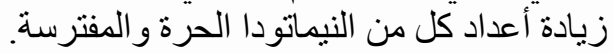

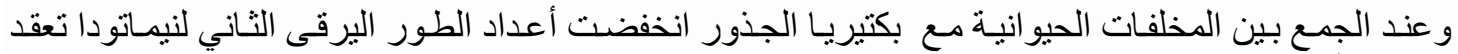

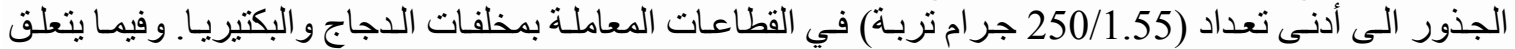

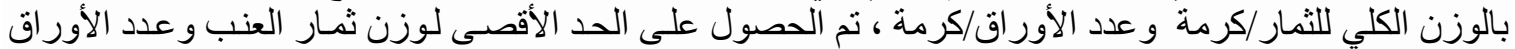

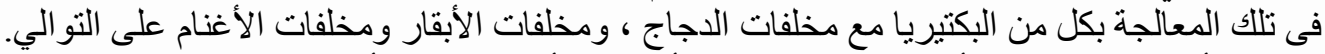

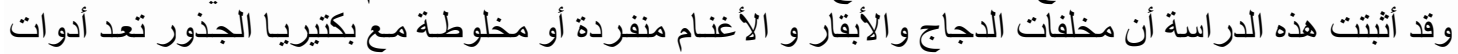

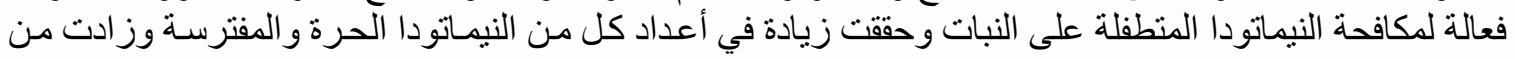

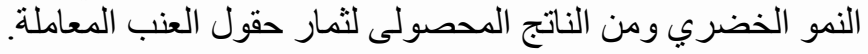

